\title{
Two Ancient Egyptian Models in the Historical Photographic Archive of the Museo Egizio, Turin
}

\author{
Tommaso Montonati
}

This article presents two case studies from the historical photographic archive of the Museo Egizio in Turin. Three photographic plates (C0629, C0630, and C0631) show two fragments of models (of a boat and of a granary) found by the Italian Archaeological Mission at Gebelein in 1914. These photos give important information about the condition of these objects at the moment of their discovery, since one of the models (boat cabin, S.15776 [?]) is currently much more fragmented than in the historical photographs, and the granary is now lost. The author focuses particularly on the chronology, spread and significance of the boat cabin's distinctive decoration style, on the basis of which he proposes a date for the (now lost) tomb where they were found. The chronology of this burial has remained hitherto moot, since no accurate date could be provided for the only other objects ascribed to its owner, Iqer, namely, two pieces of his coffin carrying Coffin Texts, labeled as G1T and G2T.

\section{ملخص البحث:}

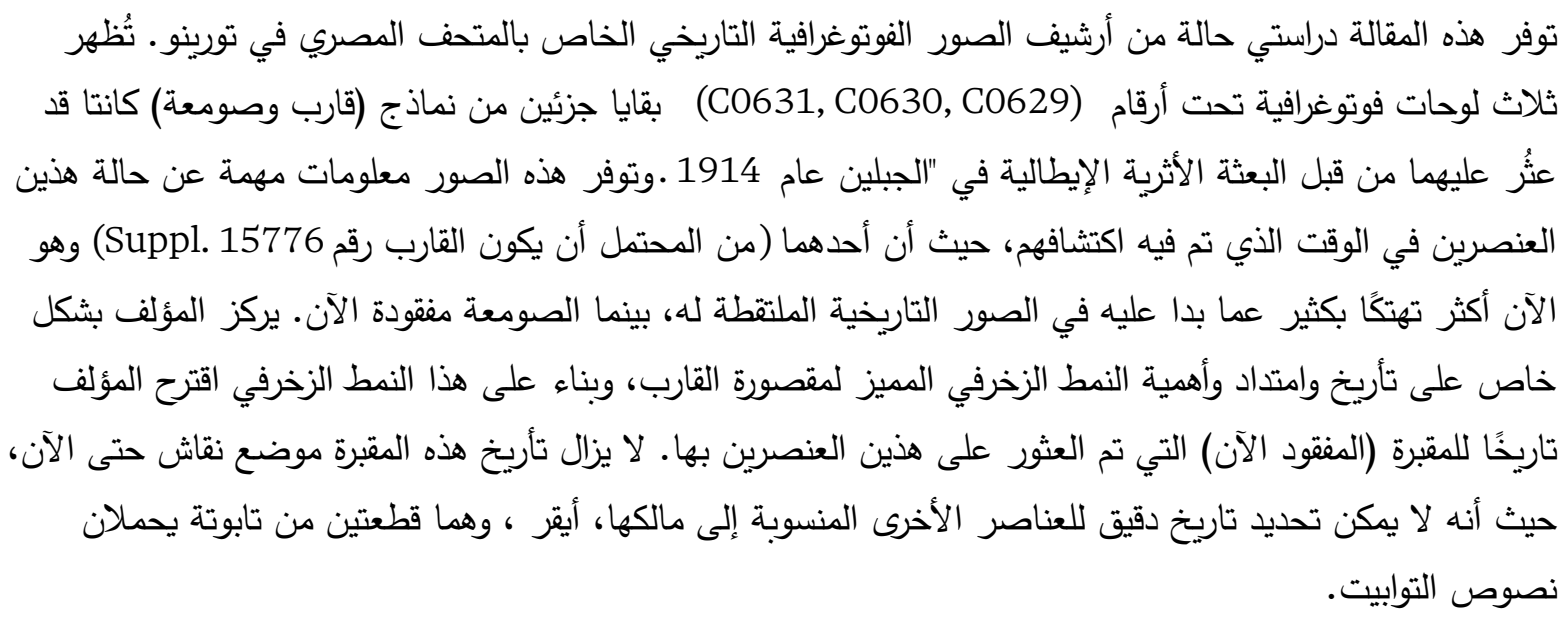

The historical photographic archive of the Museo Egizio in Turin includes many pictures of archaeological finds photographed directly in the field or at the campsite in Egypt. Between 1903 and 1937, the Regio Museo di Antichità ed Egizio conducted a series of excavation campaigns in Egypt under the direction of Ernesto Schiaparelli (1903-1906, 19081914, 1920) and then of Giulio Farina (1930, 1935, 1937). ${ }^{1}$ From the very beginning, Schiaparelli and his collaborators took a large number of photographs on glass plates (later plates on celluloid), documenting the sites and their excavation, important finds, and particular moments of life in the field. After World War II, the plates lay forgotten somewhere in the museum's storerooms. Part of them (the number is unknown) were broken or shattered due to negligence over the years. Many years later, in the Seventies, what remained was randomly stored in the general photographic archive of the museum, mixed in with other more recent glass and celluloid plates depicting the museum's galleries or objects. Unfortunately, no supplementary information related to these plates has survived; the only way of dating plates made in the field is thus to determine which 


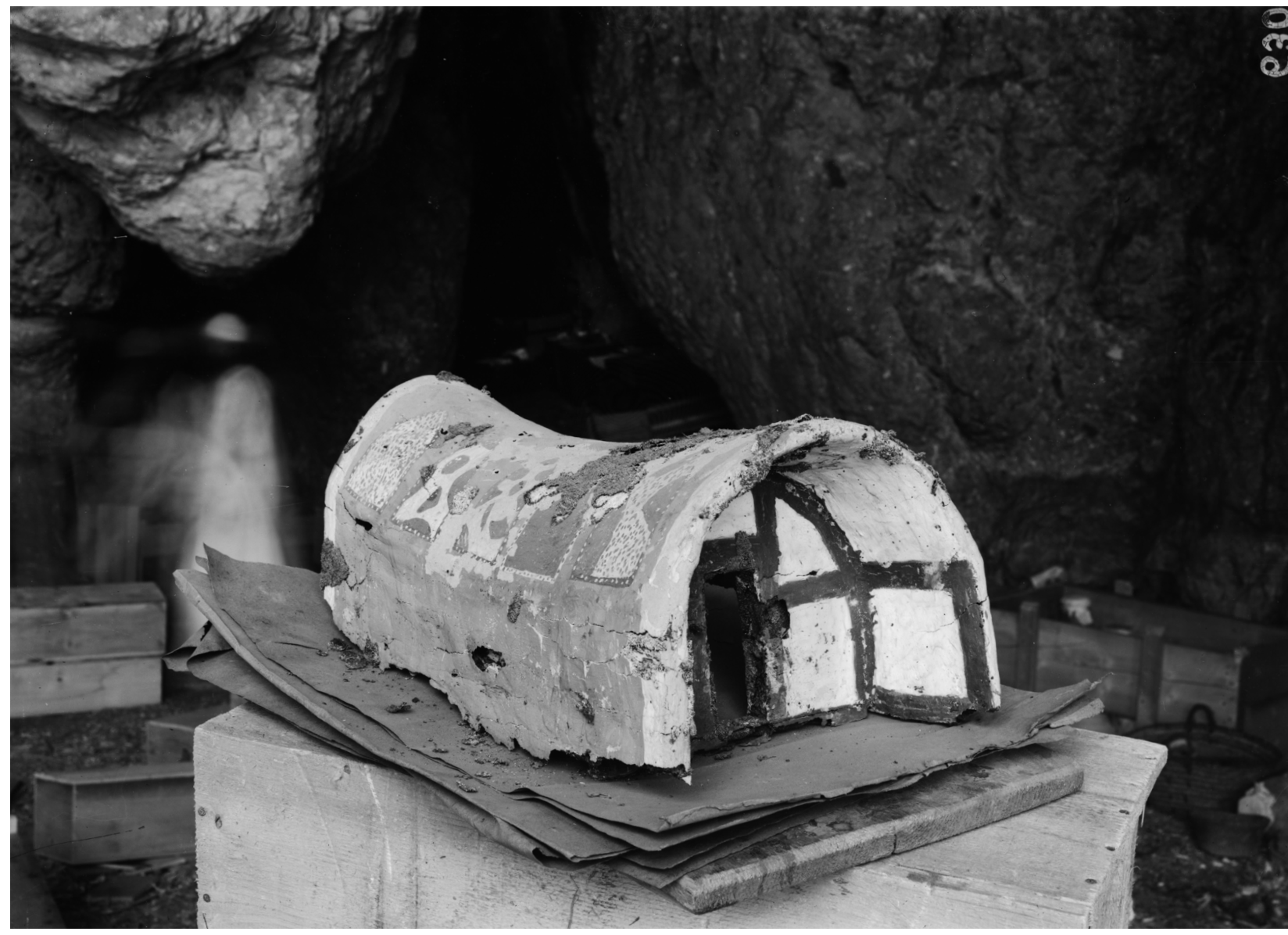

Fig. 1: Fragmentary model of a cabin, photographed at the campsite. Archivio Museo Egizio, C0630.

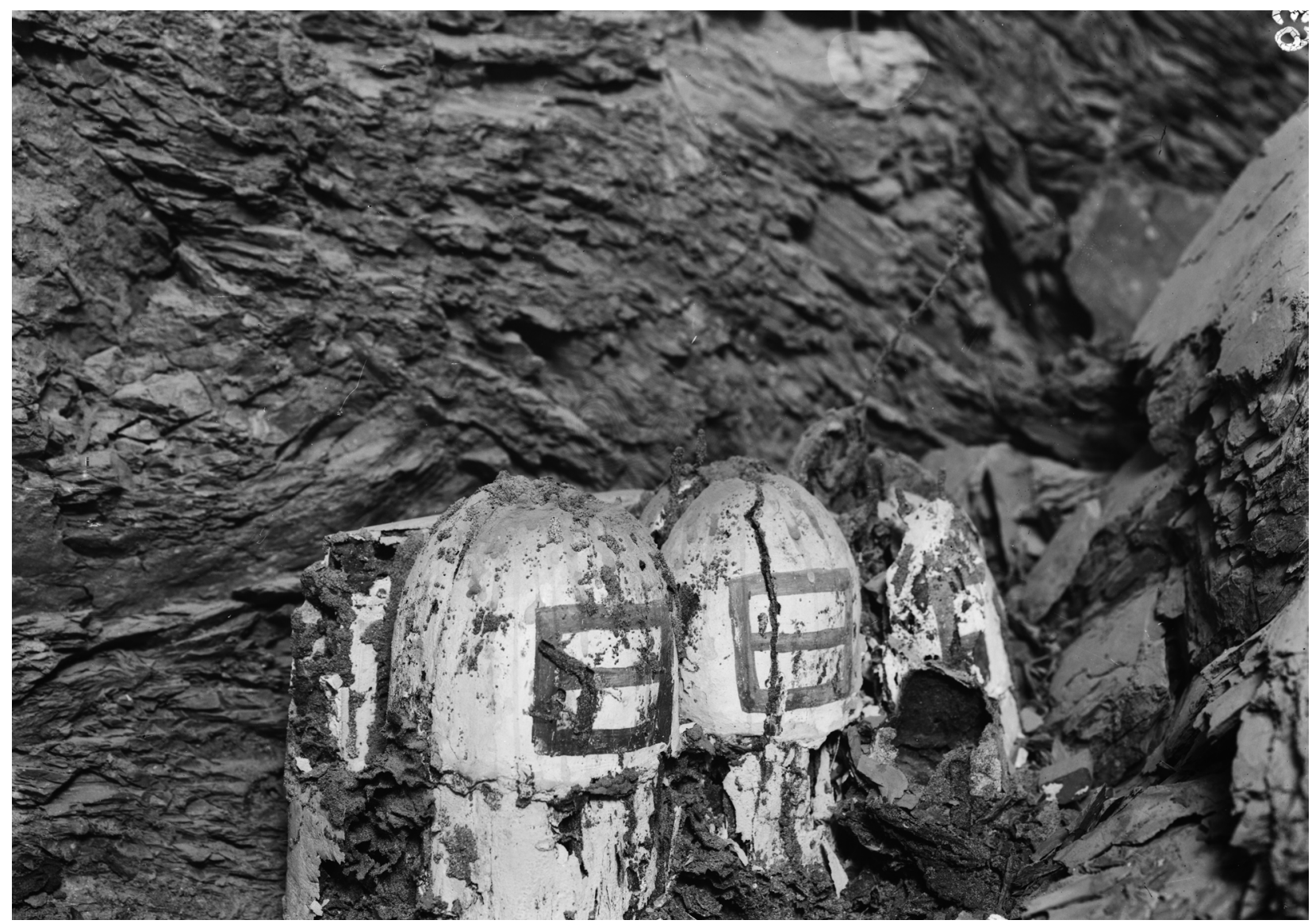

Fig. 2: Fragmentary model of a granary, photographed inside the tomb. Archivio Museo Egizio, C0631. 
site they refer to by recognizing the depicted objects, or the location. For some plates, this is rather easy to do, but for others it is hard or even impossible. Be that as it may, a remarkable photographic documentation still survives for most of the sites excavated by the Italian Archaeological Mission. ${ }^{2}$ The pictures often provide interesting information that is not found in the Mission's surviving journals, reports and letters. Furthermore, historical photographs of objects allow us to compare their present condition with their condition at the time of discovery. They also allow us to identify excavated objects that were not sent to Italy, but left behind in the storerooms of the Cairo $\mathrm{Mu}-$ seum, or were simply never collected from the field. Old excavation photographs are thus valuable insofar as they allow us to study the second life of objects, from the moment of their discovery in the field to that of their display in showcases in a museum. The present article illustrates this with a specific case study from the photographic archive of the Museo Egizio in $\mathrm{Tu}-$ rin: that of glass negative plates C0629, $\mathrm{C} 0630^{3}$ and C0631. These were made by spreading a silver bromide gel, dissolved in water, onto a $13 \times 18 \mathrm{~cm}$ glass plate, most likely developed in a darkroom at the campsite.
The three plates, which are quite well preserved, were recently digitized in the framework of the ongoing Archives Digitalization Project of the Museo Egizio. The plates show two fragments of Egyptian models (Fig. 1 and Fig. 2). Neither of these objects is listed in Schiaparelli's handwritten inventory, a numbered list of 17,386 items, encompassing all of the 11 sites excavated by the Italian Egyptologist from 1903 to 1920, as well as just short of 1900 he had purchased in Egypt prior to the launching of the Italian Archaeological Mission. Since the numbers in the Schiaparelli inventory are also used as the official museum inventory numbers, the absence of the two objects in this inventory made them hard to track down in the museum. Since they appeared in the photographs, however, they presumably came from the museum's excavations in Egypt. I thus went through the Italian Mission's written records to look for evidence confirming this.

\section{Provenance}

In spite of the lack of information accompanying the photographs, I could indeed identify the two objects they depict in the Italian archaeologists' notes. Spe-

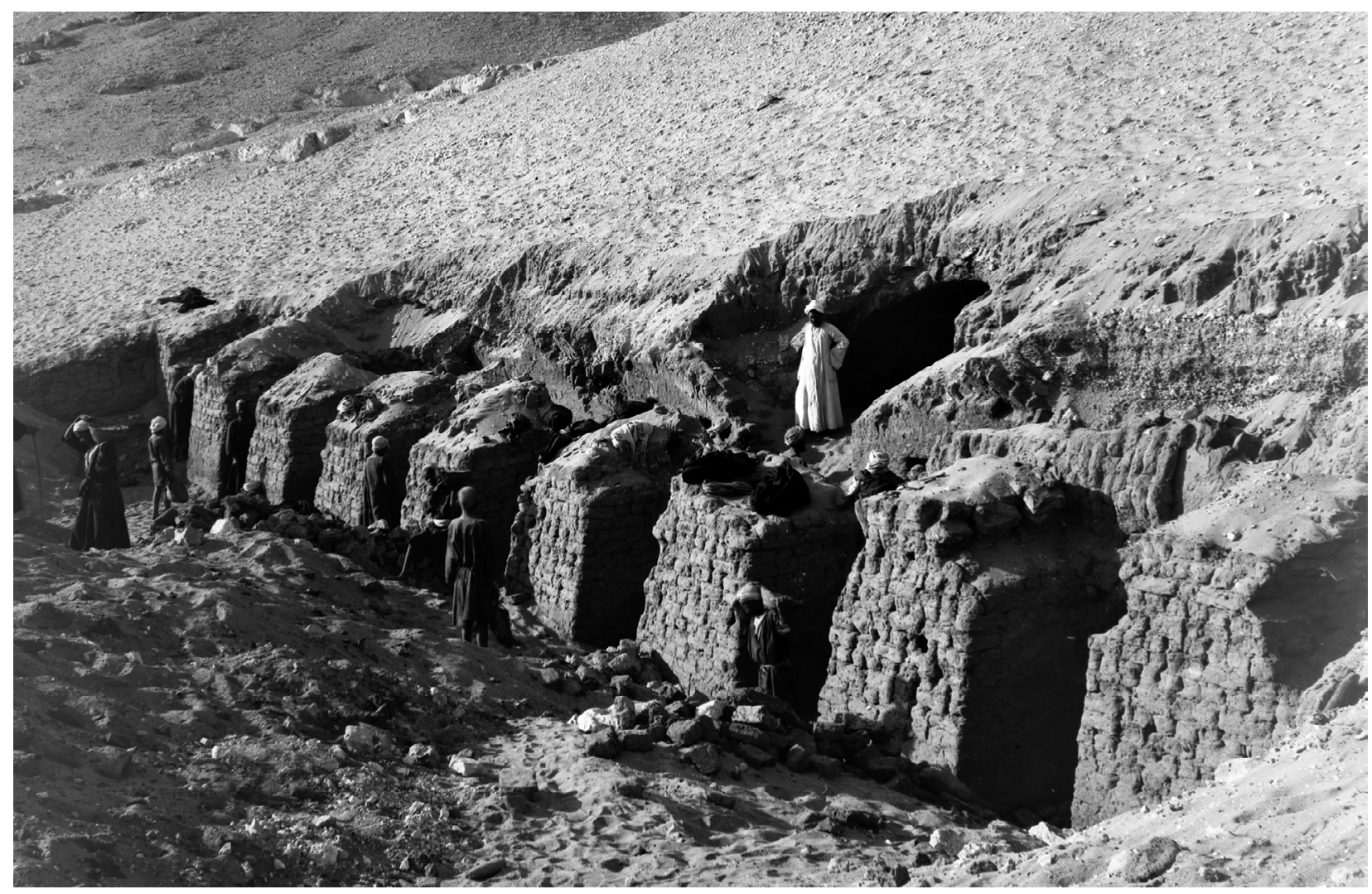

Fig. 3: View of an otherwise unrecorded First Intermediate Period-Middle Kingdom tomb during the excavation at Gebelein, probably in 1914. Archivio Museo Egizio, E0612. 
cifically, they are mentioned in records of the 1914 excavation campaign at Gebelein. ${ }^{4}$ On this occasion, Ernesto Schiaparelli, the anthropologist Giovanni Marro and the priest Michele Pizzio discovered the tomb of Pen (the name they erroneously gave, in the beginning, to an individual actually named Iqer). The tomb was excavated in the northern part of the site, which was explored by Schiaparelli between 1910 and $1920 .^{5}$ In Schiaparelli's handwritten inventory, above the original inventory number of the coffin of Iqer, we read:

To the east of the mastaba, ${ }^{6}$ a large tomb was found, similar to the painted one. ${ }^{7}$ (...) In an external chamber opening onto the corridor, at another level, more skeletons - this time ancient ${ }^{8}$ - were found, with large vases. From the central atrium, which gave access to the main funerary chamber, we discovered the bones of a sacrifice, which we left to the Museum, and in the funerary chamber fragments of a very large coffin, like the larger one in Cairo, with further inner ones, consumed by white ants. We only saved a few fragments, the inside of the innermost coffin, two wooden amulets and little more, as well as several small varnished vases. ${ }^{9}$

This is only a handwritten note; Schiaparelli did not publish anything about this discovery. He just wrote that the northern area had tombs from the "Ancient Empire" (the Old Kingdom) to the Eleventh Dynasty (Fig. 3), and planned to publish more on this subject in the future. ${ }^{10}$ Unfortunately, his plan never came to fruition.

However, detailed and enlightening information can be found in a publication of Giovanni Marro, an anthropologist and skilled photographer who worked in Egypt as a collaborator of Schiaparelli's, and wrote a memoir about his experience on excavations in Egypt some years later. Marro's writings are important because they contain the only available information about some of the tombs excavated by the mission. In 1929 (15 years after the discovery), he wrote about the grave goods found in the tomb of Iqer:

And on the bottom of the inner coffin [we found] a wooden ladder, which the mummy must have been directly laid upon. Together with some baked clay vases, many wooden objects were still there: some broken, possibly [because they had been] trampled on, others apparently intact, and among these some wooden statuettes of the deceased, some boat models, a fine granary model: all colored objects, and retaining vividness of color. (...) Only a few pictures - shot with a magnesium flash - of these objects, taken under the threat of a large slab of the vault that was about to collapse, have left us a memory of this sight, a memory full of regret. An especially fine picture shows a boat cabin with the shields of five warriors hanging from it, perfectly remindful of medieval shields in their contour, but with a singularly varied decoration, revealing the fine aesthetic and decorative sense of that primitive artist or simple craftsman. ${ }^{11}$

Marro's description of the cabin model is detailed enough for us to be sure that it is the same one shown in plates C0629-C0630. Unfortunately, since the anthropologist does not describe the granary model, we can only hypothesize that the "fine granary model" is the one shown on glass plate C0631, on the basis of the following considerations: 1) the numbering sequence, even though it was done in the Seventies, suggests that the three plates were made and stocked together, and this caused them to be numbered sequentially; ${ }^{12}$ 2) the model in C0631, photographed inside the tomb by the Italian Mission, is not present in the collection of the Museo Egizio (only one colored wooden granary is recorded from Gebelein, found in 1911 by another collaborator of Schiaparelli's, Virginio Rosa, inside the tomb of the nomarch Ini, S. 13270), and may thus have been among the grave goods which Marro and Schiaparelli left inside the tomb because of their critical condition. At the moment, this is the only testimony of its existence, and it matches with Marro's following note:

Together with the fictile furniture and an inscription, we only saved the ladder, a fine fragment of a female offering bearer, plastered and painted, and the remarkable inner facing of the last coffin, which was attached to the box with wooden dowels. ${ }^{13}$

The two models are not in Marro's above-quoted list of collected items. As I mentioned above, no further 


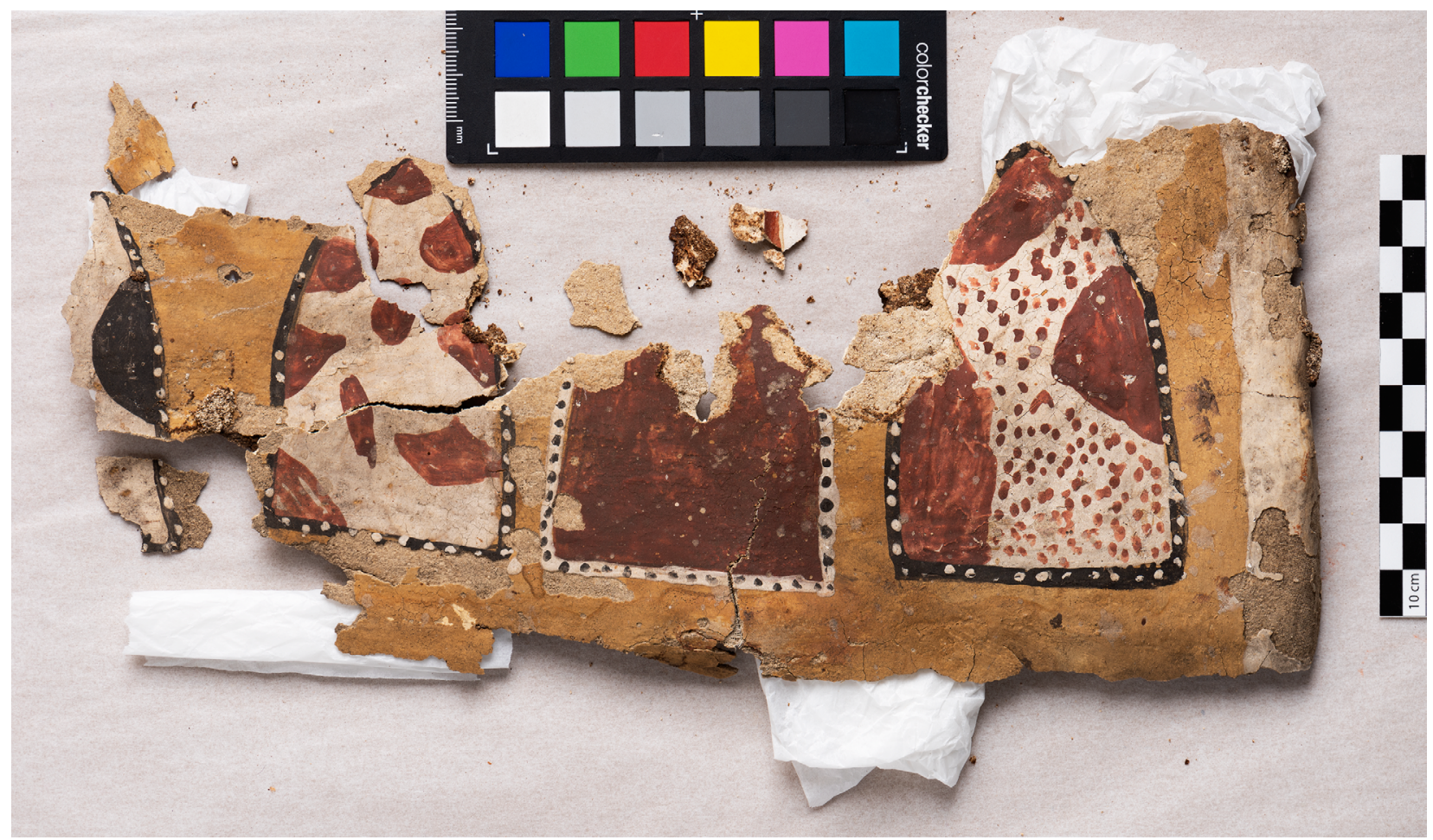

Fig. 4: The fragmentary model of the cabin today. Museo Egizio, S. 15776 (?). Photo by Nicola Dell'Aquila/Museo Egizio.

documentation is available for the granary model. As to the cabin model, I managed to track it down in the database of the Museo Egizio, under number S. 15776 (?), ${ }^{14}$ where it is described in the following terms: "Model of a vessel: fragments of the canopy on the deck, with shields made of bovine hide resting against it." ${ }^{15}$ No further information is given. The small and fragile fragments of this object currently preserved in the museum storage clearly belong to the model shown in C0629-C0630. At the moment, only the left side of the cabin survives, with only four of the original five shields, for an overall length of 30 $\mathrm{cm}$. Hopefully more fragments may turn up in the museum's storage (Fig. 4). We can now estimate that the entire cabin was about $50 \mathrm{~cm}$ long and, hence, that the complete boat was presumably more than one meter long (Fig. 5). The colors are still vivid. Red, white and black are used for the shields, ochre for the cabin walls. Some remnants of the white part of the cabin survive on the bow-ward side.

\section{Glass Plates C0629-C0630: Description}

The cabin model is interesting because of the depiction of $5+5$ shields on either side (Fig. 1, Fig. 6), depicted as being made of animal hide. Each shield has different decorations and colors, but there is no evidence that these indicate differences in rank or title, or membership of specific military corps.

Since we do not have any information about the other parts of the boat model, we can only look for parallels among other boat cabins. The shape is remindful of that of the cabins of the boat models for from the Eleventh Dynasty and the Middle Kingdom. The closest parallels are from TT280 at Deir el-Bahari, the tomb of Meketre, chancellor of kings Montuhotep II, Montuhotep III and Amenemhat I. The cabins of boats "N" and "O" have a painted structure with two shields on either side. ${ }^{17}$ Although the patterns on the shields are different and their top is more rounded, there are strong similarities, notably in the dark-colored supporting elements, the white walls, and the presence of a small porch. ${ }^{18}$ The tapered shape is similar, too. Thus, our boat possibly belonged to Reisner's Type II. $^{19}$ On the basis of a recent study featuring a sort of census of Egyptian models, ${ }^{20}$ it appears that not many boat models with cabins are attested so far, and even less with paintings of shields.

The British Museum holds a boat model (BM EA 66220) with similar features to ours. Its cabin retains traces of three shields. It was dated to the First Intermediate Period and its provenance is unknown. ${ }^{21}$ However, the date of this artifact is not based on re- 


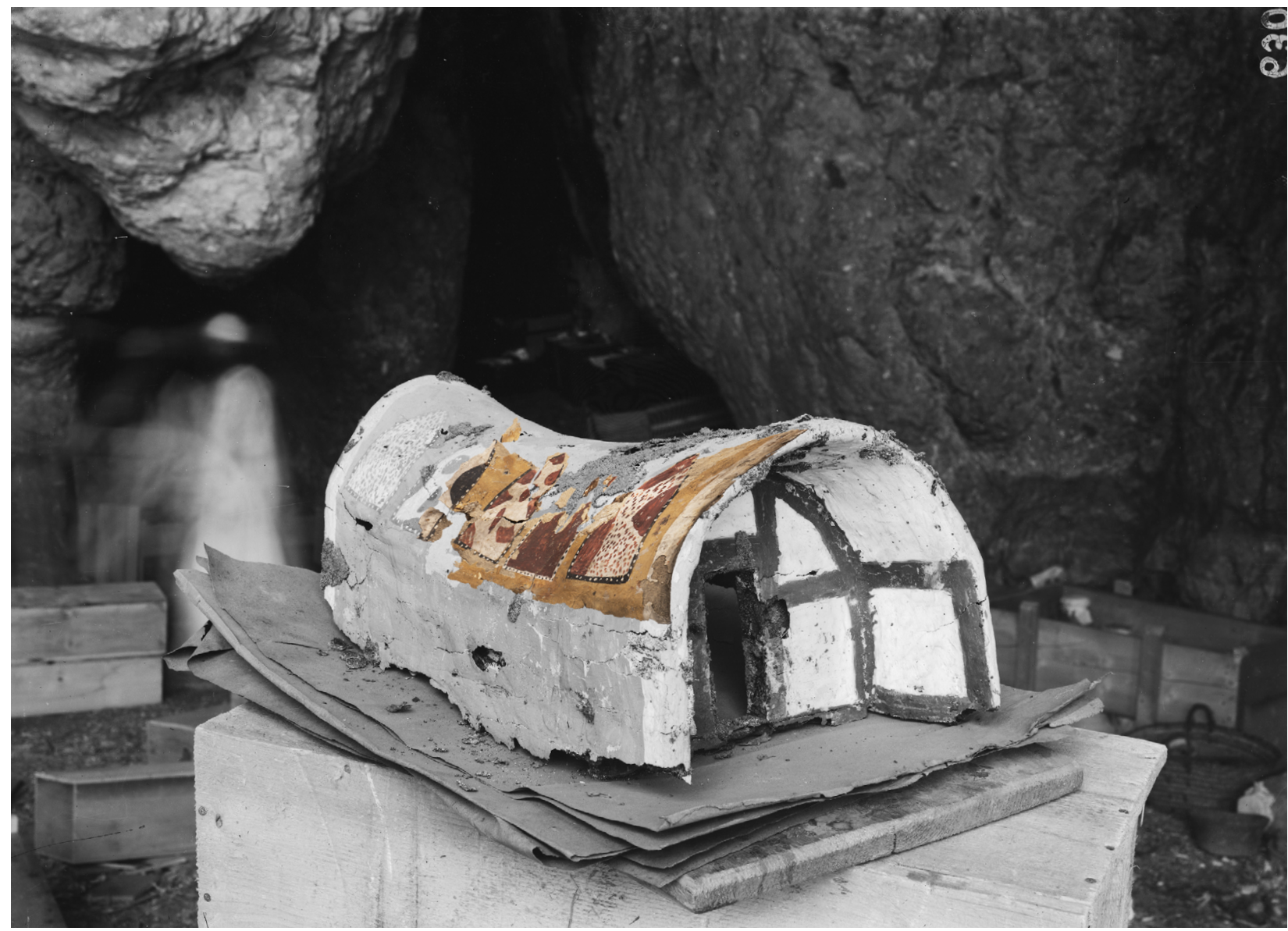

Fig. 5: The cabin fragments modeled onto the historical photo. Museo Egizio, Nicola Dell'Aquila and Alice Salvador.



Fig. 6: The other side of the cabin model, photographed at the campsite. Archivio Museo Egizio, C0629. 
liable evidence, since both the crew and the canopy seem to have been simply placed on the boat, but almost certainly do not originally belong to it. I therefore will not use it as a parallel. The Cairo Museum houses some boat models with a covering simulating animal hides, but in this case they are simple rectangular coverings, without any depiction of shields. ${ }^{22}$ Another model, however, has $1+1$ shields painted on the cabin. It is dated to the Eleventh Dynasty and comes from the tomb of Kaykhenenet at Meir. ${ }^{23}$ The Rijksmuseum in Leiden has an interesting model with $3+3$ shields on the cabin (with no visible details of animal hide), dated to the middle of Eleventh Dynasty. It belongs to the Anastasi collection and possibly comes from Thebes. Because it has a porch and because of the tapered shape of the cabin, this is an even closer parallel to our model than the boats of Meketre. ${ }^{24}$ Finally, the Metropolitan Museum of Art in New York holds a boat model (amongst others from the same tomb) from the pit burial of Senbi (possibly identifiable as the like-named nomarch hry tp c $_{3} n s p 3 t$ - from the time of Amenemhat I) at Meir, having $2+2$ shields painted on the cabin. ${ }^{25}$ This iconographic feature is also found on supports other than models, notably in tomb paintings from the First Intermediate Period. In the Museo Egizio, a wall painting from the tomb of Iti and Neferu ${ }^{26}$ shows a boat (S. 14354/07) with three shields on its cabin, very similar in shape to those on our model. In this case, we can assume that the painting depicts an everyday-life scene, showcasing the occupations of the deceased, as do other scenes in this tomb. On the boat we see some jars on the deck, some sailors at work, and three monkeys (Fig. 7). ${ }^{27}$

Two tombs of nomarchs of the Oryx nome at Beni Hasan, BHO2 of Ameny (reign of Senusret I) and BH03 of Khnumhotep II (reigns of Amenemhat II and Senusret II), both have wall paintings in their main chamber. On the north side of the east wall, in $\mathrm{BHO2}$, and the north side of the west wall, in $\mathrm{BHO}$, a funerary scene is depicted, in which boats with shields are towing the funerary boat with the coffin of the deceased under a canopy. ${ }^{28}$

Cabins, therefore, seem to be a feature of sailboats. The presence of shields on the cabin, like the inclusion of figurines of soldiers in the burial assemblage of noblemen, may allude to a military role. This may reflect the particular situation of the end of the First Intermediate Period, when every nomarch was entitled to recruit his own army, ${ }^{29}$ and even after reunification the Middle Kingdom pharaohs initially had to fight both inside and outside Egypt's national bor-

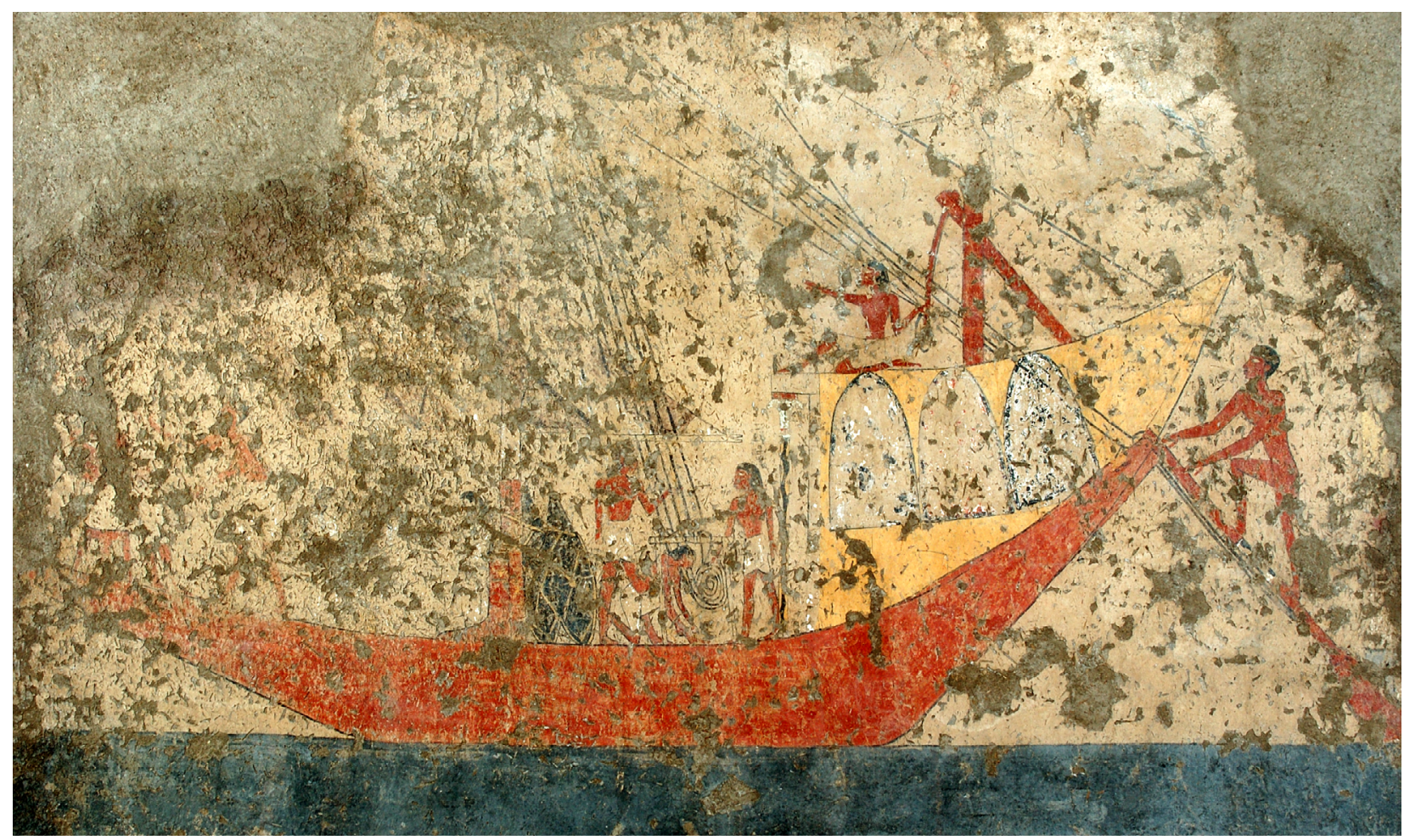

Fig. 7: Wall painting from the tomb of Iti and Neferu at Gebelein, 1911 excavation. Museo Egizio, S. 14354/07. Photo by Nicola Dell'Aquila and Federico Taverni/Museo Egizio. 
ders. ${ }^{30}$ The military shields on the cabin may also be understood as a means for a nobleman to display his strength during travel and to stress his power in the afterlife, or, on another level, as a means to protect his tomb. ${ }^{31} \mathrm{~A}$ connection between rank and decoration may be observed by considering the deceased's titles. The above-mentioned parallels for our boat models all seem to be associated with individuals having important military duties. This is true of the army chief (jmj-rз mšc) Iti - the co-owner, with Nefe$\mathrm{ru}$, of the painted tomb at Gebelein ${ }^{32}-$, of the royal chief steward and chancellor (jmj-rз htmt, jmj-rз $p r$ $w r)^{33}$ Meketre (late Eleventh-early Twelfth Dynasty), and of the nomarchs (hry-tp c $_{3} n s p 3 t$ ) of Beni Hasan and Meir (first half of the Twelfth Dynasty). It is thus quite possible that the owner of the tomb where the boat model in C0629-C0630 was found, Iqer, also had military responsibilities, although he bears no titles in the Coffin Texts on his coffin.

As far as I know, the cabin in the photograph is that with the largest known number of shields: the other boat models listed here have no more than $3+3$ shields on the cabin. The similarity of our cabin with those of the travel boats from the tomb of Meketre and that of the boat in the wall paintings of the tomb of Iti and Neferu at Gebelein suggests that this cabin was made for a boat model with the same purpose and features, and most likely from the same period. As an alternative to cabins, some boat models have canopies. Sometimes these canopies are also graced with painted shields. ${ }^{35}$ Other boat models carry three-dimensional representations of shields. Boat models with canopies graced with shields or three-dimensional representations thereof number at least 25 , scattered in museums across the world. They seemed to have served as pilgrimage boats, allowing the deceased to ideally travel to pilgrimage destinations such as Abydos.

At Beni Hasan, a canopy was found inside Tomb 575 of Khetia (Eleventh Dynasty). ${ }^{36}$ Tomb 723 of Sebek-Hetepa (late Eleventh Dynasty) yielded a boat with black-and-white spotted shields. ${ }^{37}$ A model having $1+1$ shields on the top of the canopy possibly come from Tomb 700. ${ }^{38}$

Three canopies from Sedment, excavated by W. M. F. Petrie and G. Brunton, ${ }^{39}$ are all decorated with $2+2$ shields. One was found in the burial of Mertetes
(Tomb 2112), possibly dated to the Heracleopolitan Dynasty; ${ }^{40}$ another, from Tomb 2107, is now at the Victoria Museum for Egyptian Antiquities in Uppsala; ${ }^{41}$ a third was found in Tomb $2105 .{ }^{42}$

At El-Bersheh, four models with detached canopies (all having $2+2$ shields) were found in the tomb of Djehutynakht (Eleventh Dynasty, tomb 10A). ${ }^{43}$ Another similar model, dated to the mid-Eleventh Dynasty, has $3+3$ shields on the top of the canopy. ${ }^{44}$ Another model, of Nehri, having $2+2$ shields on the top of the canopy, is dated to the early Twelfth Dynasty. ${ }^{45}$ Barely visible shields can be made out on the canopy of a boat dated to the Eleventh Dynasty. ${ }^{46} \mathrm{~A}$ last model, found in 1898, had 5+5 small red and black shields on the top. ${ }^{47}$

At Deir el-Bahari, the tomb of Meketre also yielded some models having canopies with shields depicted on the top. ${ }^{48}$ Moreover, in Pit 28 of Treasurer Buau, in the temple of Montuhotep, a boat with a canopy graced with stylized animal hide shields was found. ${ }^{49}$

From Abusir, the tomb of the regulator of the phyle and chief of the estate of the pyramid of Nyuserre, Harshefhotep I (late Eleventh Dynasty), contained 2 boats, both with $1+1$ black and white shields on the canopies. ${ }^{50}$

Finally, from Saqqara, tomb 2757 of Anpuemhat and Usermut (late Eleventh Dynasty) yielded a model with $2+2$ shields depicted on the top. ${ }^{51}$

3D models of shields sometimes appear on boats, arranged next to the canopy - as in the case of two boats from Tomb 186 of Nefwa (Eleventh Dynasty; a third boat, JE 37564b, has armed men ${ }^{52}$ and one from the tomb 585 of Khnumnakht at Beni Hasan (late Eleventh - early Twelfth Dynasty) ${ }^{53}$, - or in the middle of the boat, as in the case of a specimen from Tomb 3 of Nehri and another from the first shaft of Amenemhat, both in el-Bersheh (early Twelfth Dynasty). ${ }^{54}$ Other armed men equipped with shields were found on a boat from the tomb of Karenen at Saqqara (Teti necropolis, early Twelfth Dynasty). ${ }^{55}$ As we can see, at the moment it seems that the use of depicting shields on boat models was relatively short-lived, being related to the role of dignitaries who lived in rather turbulent times. Some of these dignitaries had clearly military duties, and this may explain the presence of this decorative motif on the models found in their burials. 
The typology of shields used in ancient Egypt changes over times. The ten shields depicted on the cabin in the photographic plates are of an Eleventh Dynasty-Middle Kingdom type with a flat lower edge and arched top, ${ }^{56}$ known as "apex shields". ${ }^{57}$ These shields are typically made of animal hide. The type very likely arrived in Egypt at the beginning of the First Intermediate Period, since no specimens are known before, when local Upper Egyptian rulers hired Nubian ("Group C") soldiers for their own armies, mostly as bowmen, especially at Gebelein. ${ }^{58}$ Moreover, the use of depicting shields on the cabins or canopies of boat models seems to be restricted to a narrower time range, extending from the middle of the First Intermediate Period to the first half of the Twelfth Dynasty, in tombs of high-ranking military officials..$^{59}$ Further investigations may confirm or extend this time range. Shields made of animal hide continued to be used as defensive weapons, although they change in shape (a more rounded top) and do not seem to occur as models anymore. Two shields found inside the tomb of Tutankhamun (KV62) are made of antelope hide and another two of cheetah skin, and an interesting painting in TT40 (tomb of Huy) shows Nubians offering shields, some of them made of animal hide. ${ }^{60}$ This could mean that such shields continued to exist in later times, alongside new types, in southern regions such as at Kush. So far, the ten shields painted on the cabin make our model a unicum, possibly belonging to an otherwise unattested local style. This model was part of the burial assemblage of a dignitary who lived between the end of the Eleventh and the beginning of the Twelfth Dynasty, as is the case for most of the other examples we have looked at (Table 1 and Table 2). It is particularly similar to the models of Meketre, possibly dating from after the death of Montuhotep II, ${ }^{61}$ and to the ship depicted in the tomb of Iti and Neferu at Gebelein.

\section{Granary model - Glass Plate C0631}

The second object shown in glass plate C0631 is a granary model apparently consisting of a single row of three vaulted silos (the third is very damaged, see Fig. 2) with an opening on one side, rendered by rectangular lines drawn on the front of each silo. It is remindful of the granaries painted in tomb decoration, where the apertures are regularly depicted on the front instead of on the top. As I observed previously, the consecutive numbering of this glass plate and the other two mentioned above suggests that the three plates were made, used and, consequently, stocked together. Our model appears to be seriously damaged, so we cannot tell whether the visible silos adjoined a rectangular enclosure or a second row of silos. It possibly resembled a clay granary model sold in Luxor at the end of the nineteenth century. ${ }^{62}$ Since the object is nowhere to be found in the Museo Egizio and we lack any further information about it, we must assume that, unlike the boat model, it was left in the tomb. It may have been among the wooden grave goods that crumbled to pieces as soon as

\begin{tabular}{|c|c|c|c|c|}
\hline & Gebelein & West Thebes & Meir & Beni Hasan \\
\hline $\begin{array}{l}\text { First Intermediate } \\
\text { Period }\end{array}$ & $\begin{array}{l}\text { Wall paintings from the } \\
\text { painted tomb of Iti and } \\
\text { Neferu }(3)^{34}\end{array}$ & & & \\
\hline Mid Eleventh Dynasty & & $\begin{array}{l}\text { Model from Anastasi } \\
\text { collection in Leiden, AH } \\
63(3+3)\end{array}$ & $\begin{array}{l}\text { Model from tomb of } \\
\text { Kaykhenenet }(1+1)\end{array}$ & \\
\hline $\begin{array}{l}\text { Late Eleventh-early } \\
\text { Twelfth Dynasty }\end{array}$ & $\begin{array}{l}\text { Cabin in photos C0629- } \\
\text { C0630 }(5+5) ?\end{array}$ & $\begin{array}{l}\text { Models in tomb of } \\
\text { Meketre }(2+2)\end{array}$ & & \\
\hline $\begin{array}{l}\text { First half of the } \\
\text { Twelfth Dynasty }\end{array}$ & $\begin{array}{l}\text { Cabin in photos C0629- } \\
\text { C0630 }(5+5) ?\end{array}$ & & $\begin{array}{l}\text { Model from tomb of } \\
\text { Senbi }(2+2)\end{array}$ & $\begin{array}{l}\text { Wall painting from Tomb } \\
2 \text { of Ameny (2) }\end{array}$ \\
\hline Mid Twelfth Dynasty & & & & $\begin{array}{l}\text { Wall painting from Tomb } \\
3 \text { of Khnumhotep II (2) }\end{array}$ \\
\hline
\end{tabular}

Table 1: Geographical and chronological chart of models of boats or paintings of boats having cabins decorated with shields. 


\begin{tabular}{|c|c|c|c|c|}
\hline & Ninth-Tenth Dynasty & FIP (generic) & Eleventh Dynasty & Twelfth Dynasty \\
\hline Abusir & & & Tomb of Harshefhotep I & \\
\hline Saqqara & & & $\begin{array}{l}\text { Tomb of Anpuemhat and } \\
\text { Usermut }\end{array}$ & Tomb of Karenen \\
\hline Sedment & \begin{tabular}{|l} 
Tomb 2105 \\
Tomb 2107 \\
Tomb 2112 of Mertetes
\end{tabular} & & & \\
\hline Beni Hasan & & & \begin{tabular}{|l} 
Tomb of Khetia \\
Tomb of Sebekhetepa \\
Tomb 700 \\
Tomb of Nefwa \\
Tomb of Khnumnakht
\end{tabular} & $\begin{array}{l}\text { Tomb painting of } \\
\text { Ameny } \\
\text { Tomb painting of } \\
\text { Khnumhotep I }\end{array}$ \\
\hline Deir el-Bersha & & & $\begin{array}{l}\text { Tomb of Djehutynakht: } \\
\text { Harvard Semitic } \\
\text { Museum 1902.16.3 } \\
\text { Leiden F1939/1.2 } \\
\text { Cairo JE } 4952\end{array}$ & $\begin{array}{l}\text { Tomb of Nehri } \\
\text { Tomb of Nehri }\end{array}$ \\
\hline Meir & & & Tomb of Kaykhenenet & Tomb of Senbi \\
\hline Thebes & & Leiden AH 63 & $\begin{array}{l}\text { Tomb of Meketre } \\
\text { Tomb of Meketre } \\
\text { Tomb of Buau }\end{array}$ & \\
\hline Gebelein & & $\begin{array}{l}\text { Tomb painting of Iti } \\
\text { and Neferu }\end{array}$ & Tomb of Iqer (?) & \\
\hline Unknown provenance & & BM EA 66220 (?) & & \\
\hline
\end{tabular}

Table 2: Geographical and chronological chart of depictions of shields on boats. In red, cabins with shields; in blue, canopies with shields; in green, 3D shield models on boats.

Schiaparelli and Marro tried to gather them.

It is an unusual model, since during the First Intermediate Period and Middle Kingdom granary models occur in different types and materials, including wooden flat-roofed square granaries and clay granaries, some similar to the wooden ones, as well as others having silos with domes and holes on the top or on the front; these last sometimes are located inside a pillared hall. ${ }^{63}$ The model in the photograph shows a mixture of styles. In her unpublished $\mathrm{PhD}$ thesis, Angela Tooley argues that models of this type, which date from the Old to the Middle Kingdom, are rarely made of wood. ${ }^{64}$ Indeed, very few wooden specimens are known. One is from el-Mo'alla: ${ }^{65}$ the two pieces of the model are very small, with a square opening on the front side. Two other models have been found in the Naga ed-Deir necropolis: one in tomb N3795, dated to the First Intermediate Period, the other in tomb N241, dated to the end of the old Kingdom. ${ }^{66}$ Clay silos, instead, are more frequent. The Museo Egizio holds three clay storeroom mod- els, dating back to the late Old Kingdom or the First Intermediate Period (Figs. 8, 9). ${ }^{67}$

Granaries of this kind are commonly depicted in tomb paintings of this period and of the Middle Kingdom. Nevertheless, the light colors used for our model (likely white or light yellow) are unusual, since in paintings granaries are usually of dark colors. At Gebelein, such granaries are depicted on the coffin of Iqer itself (Fig. 10), in the tomb of Iti and Neferu (Fig. 11), and on the coffin of Henuy. ${ }^{68}$ In other southern necropoleis, examples are known at Aswan, in the tomb of Sarenput (reign of Senwosret I), ${ }^{69}$ at el-Mo'alla, in the tombs of Ankhtify (Ninth Dynasty) ${ }^{70}$ and Sobekhotep (First Intermediate Period), ${ }^{71}$ at Thebes, on the sarcophagi of queen Ashit ${ }^{72}$, princess Kawit ${ }^{73}$ and general Intef ${ }^{74}$ (TT386, reign of Montuhotep II before the reunification), and on a wall painting from TT60 of Antefoker and Senet (reign of Senwosret I $)^{75}$. Further examples are to be seen in the painted decoration of the tombs of Ameny, ${ }^{76}$ Kheti $^{77}$ and Baket III ${ }^{78}$ at Beni Hasan or on 


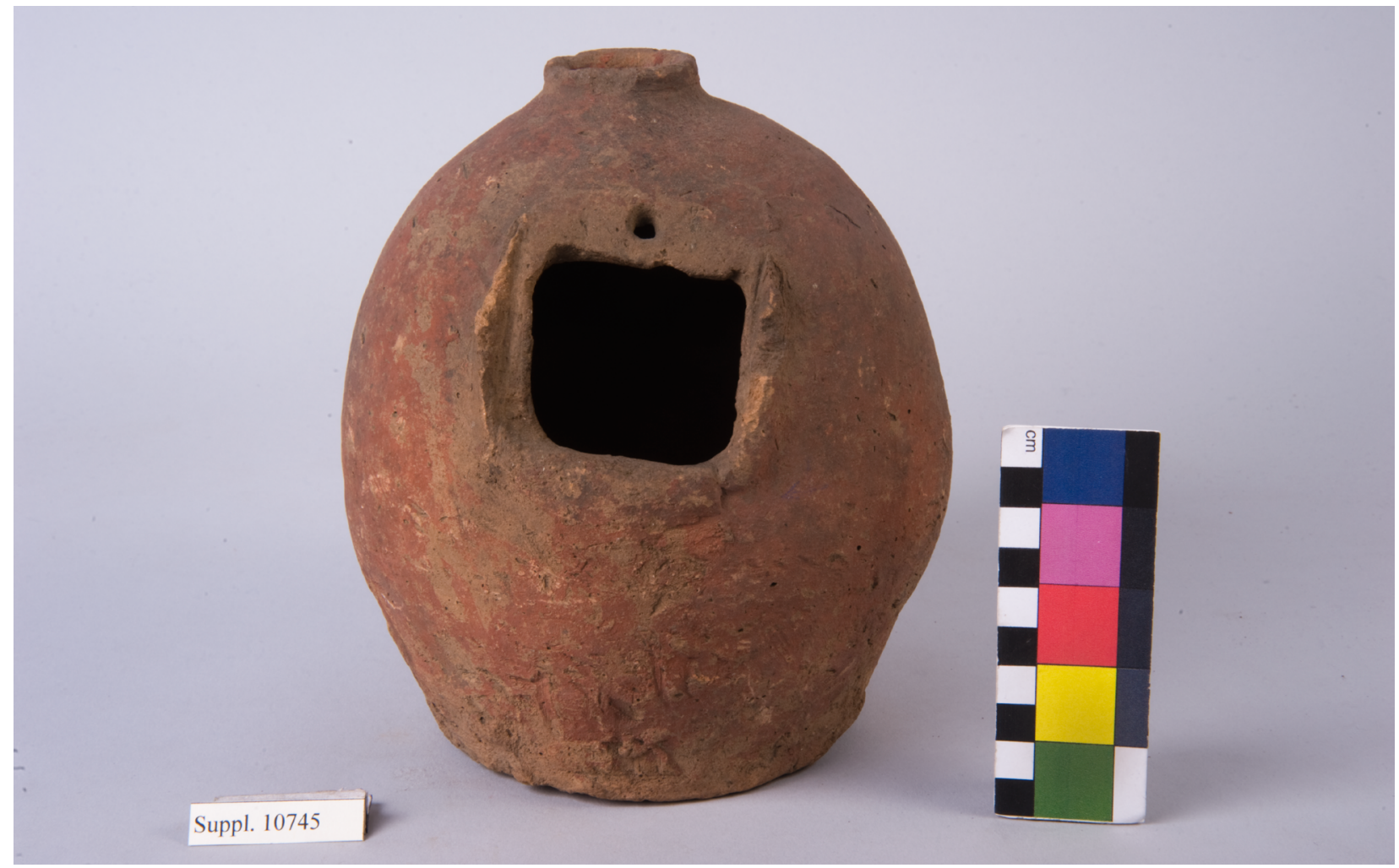

Fig. 8: Baked-clay model of a granary, from Asyut, 1910 excavation. Museo Egizio, S. 10745. Photo by Museo Egizio.

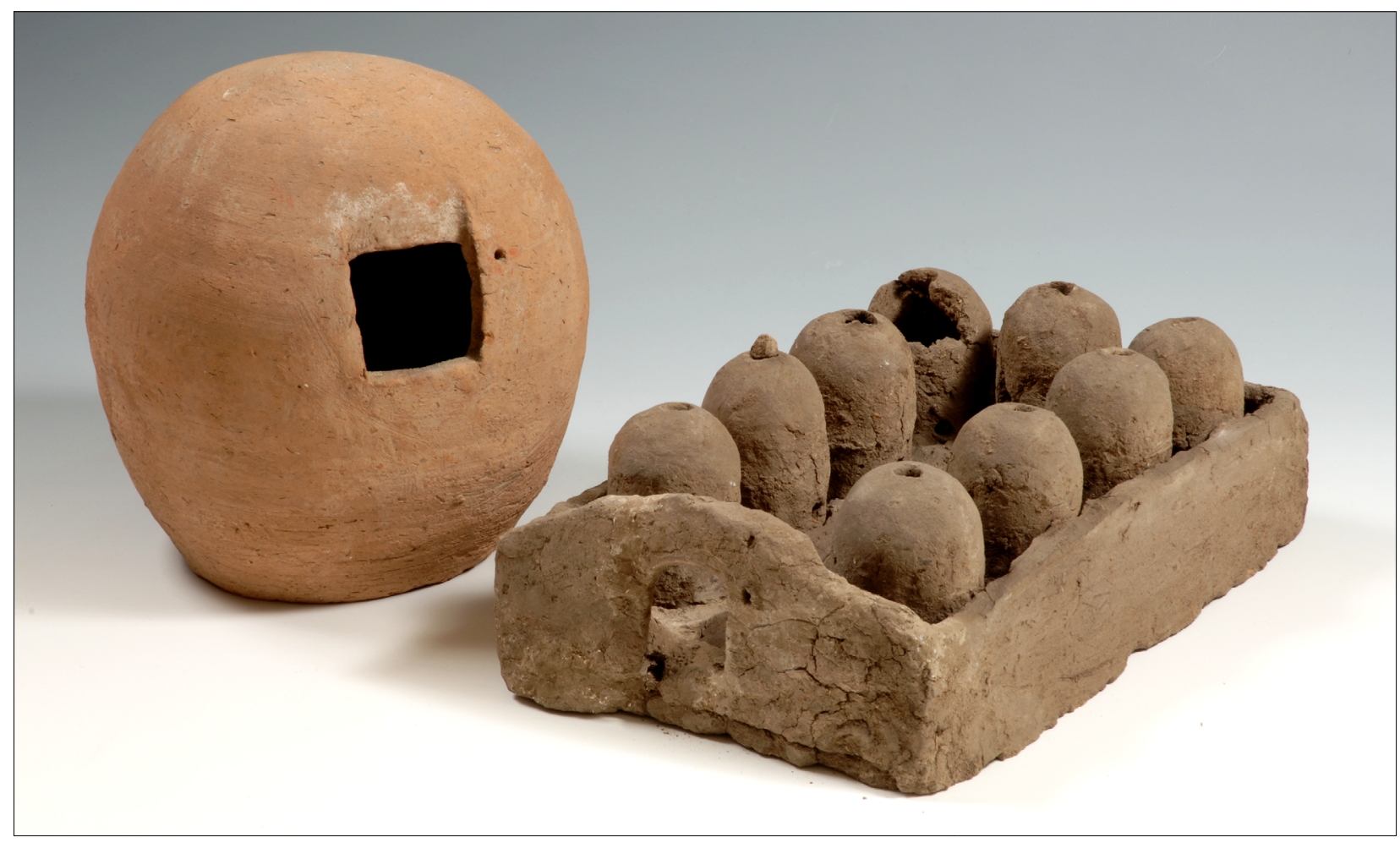

Fig. 9: Clay models of granaries, from Gebelein, 1910 and 1914 excavations. Museo Egizio, S. 11960, S. 15802. Photo by Nicola Dell'Aquila and Federico Taverni/Museo Egizio.

several coffins discovered at Asyut and Deir el-Bersha. An early example, different in colors but similar in shape, can be recognized in a tomb painting of the nomarch Pepyankh-herib, lord of Meir in the time of

\section{Pepi II. ${ }^{79}$}

Is it possible to narrow down the date of the cabin in C0629-C0630 and the granary in C0631 by considering the rest of Iqer's burial assemblage? We know 


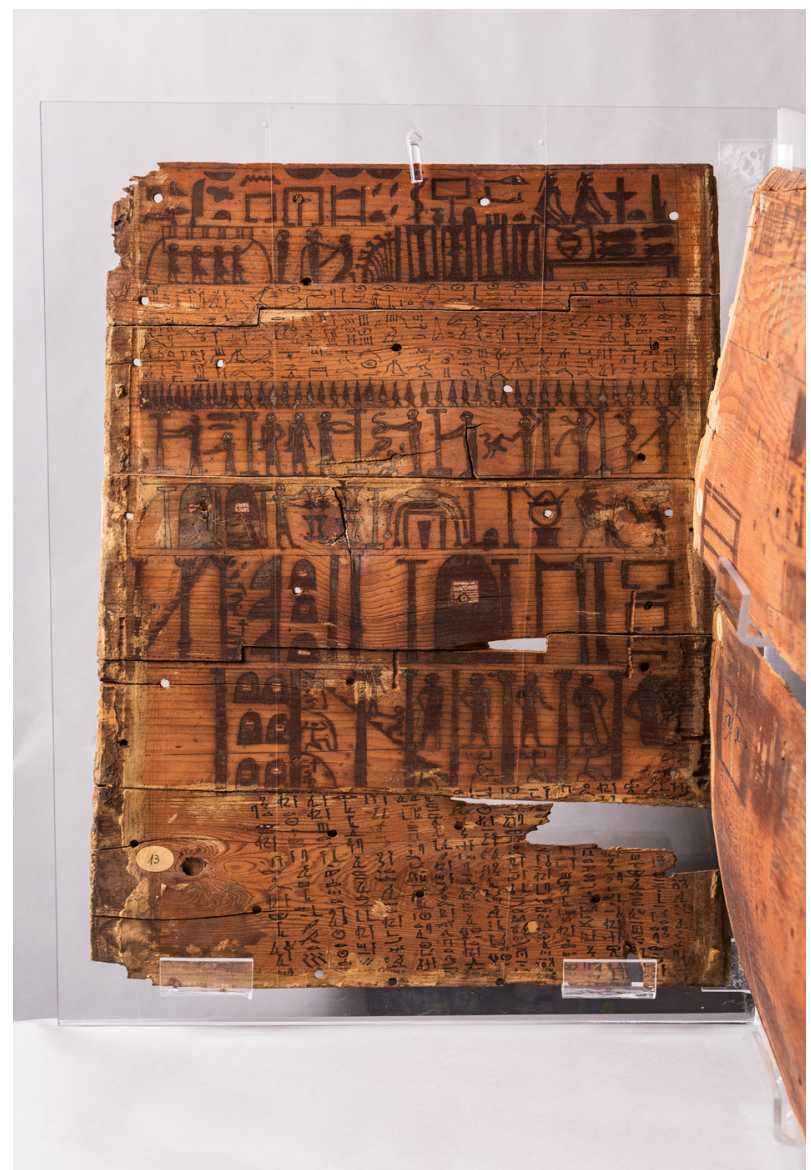

Fig. 10: Coffin of Iqer, from Gebelein, 1914 excavation. Museo Egizio, S. 15744. Photo by Nicola Dell'Aquila and Federico Taverni/Museo Egizio. very little about Iqer, except for the archaeologists' descriptions mentioned above. So far, the only dating elements in the assemblage are the astronomic calendar and the Coffin Text spells on his coffin, ${ }^{80}$ found by the Missione Archeologica Italiana and now partly held by the Museo Egizio (in a very ruined state, as previously noted). ${ }^{81}$ In addition to the coffin (S. 15744/01), ${ }^{82}$ Iqer's burial assemblage includes a ladder-shaped support for the mummy (S. 15744/02), a model spear and a model boomerang (both inventoried under S. 15744/03). ${ }^{83}$ The tomb is still far from having an accepted specific date. Some scholars date the coffin to the second half of the Twelfth Dynasty ${ }^{84}$ others prefer to date it between the late Eleventh Dynasty and the early Twelfth Dynasty. ${ }^{85}$ The two models, and especially the boat cabin, can help us dispel this uncertainty: their affinity with Meketre's models and the paintings from the tomb of Iti is an argument in favor of the earlier date for the coffin, and for Iqer himself. A date in the second half of the Twelfth Dynasty could only be upheld if we admitted that the models are instances of the lingering of an old style in the provincial site of Gebelein, as Leospo and other scholars have argued

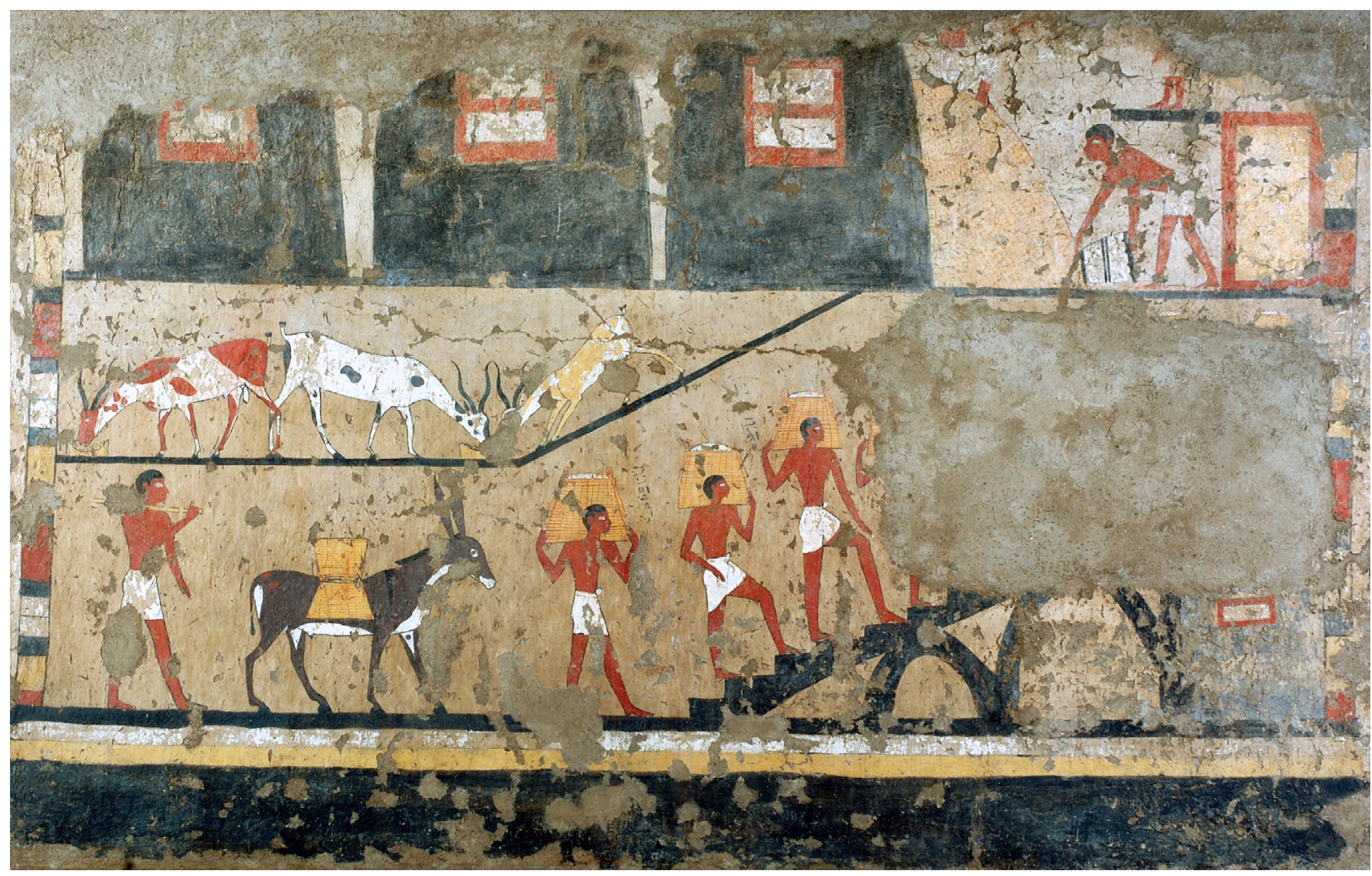

Fig. 11: Wall painting from the tomb of Iti and Neferu, Gebelein, 1911 excavation. Museo Egizio, S. 14354/15. Photo by Nicola Dell'Aquila and Federico Taverni/Museo Egizio. 
regarding the coffin. ${ }^{86}$ However, I find this second hypothesis too conjectural to be viable.

\section{An early Middle Kingdom workshop style?}

The same contrast between light and dark colors observable on our two models is also displayed by the storeroom model from the tomb of Henuy, excavated at Gebelein in the northern area in 1899 by a German mission and dated to the Twelfth Dynasty. ${ }^{87}$ Tooley later questioned this date, suggesting an earlier one. ${ }^{88}$ There seems to be a certain similarity in the use of colors; in particular, the dark color - usually brown - is used for highlighting structural elements. In the boat model, it is used for the wooden framework of the cabin. In granary models, such as the Steindorff model and the examples in the Museo Egizio (Plate C0631 and the painted examples from the tomb of Iti and on the coffin of Iqer), brown is used to highlight the wooden structural elements of apertures (silo mouths, storeroom doors). All these artifacts apparently date to the end of First Intermediate Period or beginning of the Middle Kingdom, and possibly originate from the same local workshop. Angela M.J. Tooley has recognized a sort of Gebelein Style for models from the first half of the First Intermediate Period, ${ }^{89}$ with particular reference to the intact tomb of the nomarch Ini, found in 1911 by Virginio Rosa, a collaborator of Schiaparelli's. ${ }^{90}$ However, Ini lived before Iqer's time. The only boat cabin at Gebelein comparable with the cabin in plates C0629-C0630 is thus that of the ship in the tomb of Iti and Neferu, repeatedly referred to above. This tomb is still far from being well dated; it is nevertheless certainly later than the time of the nomarch Ini, who lived in the First Intermediate Period. We can say the same for the granary: the only silos comparable with those shown in the plate are those depicted in the tomb of Iti and on the coffin of Iqer from the same burial as the model. In a recent work, G. Eschenbrenner-Diemer has singled out four chronological phases in wooden model manufacturing. ${ }^{91}$ The site of Gebelein is mentioned for phase II, with regard to Ini's models (dated, as mentioned, to the First Intermediate Period). At the moment, thanks to these photos, we can assume the existence of a later provincial workshop at Gebelein, to be included in her phase IIb or III, ${ }^{92}$ at the beginning of the Twelfth Dynasty, possibly influenced by the Theban region.

Since our cabin is also very similar to the cabins of the boats found in Meketre's tomb, it is possible to suggest an influence from the capital, before the royal court moved north. Gebelein is about $30 \mathrm{~km}$ south from Thebes, and could easily have received an influence from there or even hosted a Theban craftsman. It is significant, in this regard, that some scholars believe that in Iqer's time, spanning the late First Intermediate Period and the early Middle Kingdom, the region of Gebelein had already been conquered by Theban rulers. The storeroom model in the photo is rather damaged, with only one row of silos and traces of a wall (of an enclosure?) behind the silos: this could be a regional variant, especially considering the lack of silos among the models of Meketre. In this case, wall paintings cannot help, since they usually show silos painted in dark colors such as black. We cannot say whether our fragment was part of a bigger model similar to the square ones; in any case, silos with domes are quite a singular feature for a wooden model, which so far stands as a unicum in the Gebelein area. 


\section{Notes}

${ }^{1}$ Schiaparelli, ASAE 21 (1921), pp. 126-28; Schiaparelli, Relazione sui lavori, I, 1924, and Relazione sui lavori II, 1927; Farina, Aegyptus 10 (1930), n. 2/4; Farina, Oriente Moderno 17 (1937). Moiso, Ernesto Schiaparelli e la tomba di Kha, 2008; Moiso, La storia del Museo Egizio, 2016; Del Vesco and Moiso (eds.), Missione Egitto, 2017; Museo Egizio's unpublished documents now kept at the State Archive in Turin.

${ }^{2}$ M.A.I. (Missione Archeologica Italiana) was founded and directed by Ernesto Schiaparelli until his death on February 14, 1928, and, after him, by the archaeologist Carlo Anti, Professor at the University of Padua. Anti led some excavations in Egypt, notably that of Tebtynis, and Giulio Farina, who did some digging in Egypt himself, reported to him. The Museum's photographic archive only holds photos relative to Schiaparelli's and Farina's excavations, not Anti's. ${ }^{3}$ The picture is published in Donadoni Roveri et al., Il Museo Egizio di Torino, $1993^{2}$, p. 53. In the label, however, we only read: "The cabin of a wooden boat with paintings of shields on it, as found at the moment of its discovery" (translated from the original Italian).

${ }^{4}$ The Italian mission conducted seven campaigns at this site (1910, 1911, 1914, 1920, 1930, 1935, 1937), but detailed documentation is only available for 1910 and 1911, respectively consisting of Schiaparelli's excavation notes (Archivio di Stato in Turin, MAE funds, $3^{\circ}$ vers., m. 2, n. 13) and the journal of his collaborator Virginio Rosa (Archivio di Stato in Turin, MAE funds, $2^{\circ}$ vers., m. 5, n.2); the remaining campaigns are only documented by very brief notes. ${ }^{5}$ Schiaparelli, ASAE 21 (1921).

${ }^{6}$ Mastaba of Perim, Fourth Dynasty, see Donadoni Roveri et al. (eds.), Gebelein, 1994.

${ }^{7}$ The reference is to the painted tomb attributed to Iti and Neferu, dated to the First Intermediate Period.

${ }^{8}$ Compared to previous skeletons found in the corridor which dated from the Ptolemaic Period.

9 "A oriente del mastaba si rinvenne una grande tomba, sul tipo di quella dipinta. (...) In una camera esterna che si apriva sulla galleria ed in altra altezza, si trovarono altri scheletri, questi antichi, con grossi vasi. Dall'atrio centrale, penetrativi poi sulla camera sepolcrale principale, trovammo, nel luogo, le ossa di una vittima, che lasciammo al Museo, e nella camera sepolcrale, i resti di un grandissimo sarcofago, come il maggiore del Cairo, con altri interni, consumato dalle formiche bianche. Salvammo soli pochi frammenti, l'interno dell'ultima cassa, due amuleti di legno e poco altro, nonché i vari vasetti verniciati." Archivio di Stato di Torino, MAE fund, $2^{\circ}$ vers., m. 2, n. 22.

${ }^{10}$ Schiaparelli, ASAE 21 (1921), p. 128.

11 “... e sul fondo del sarcofago interno una scala pure di legno, sopra la quale doveva essere stata distesa direttamente la mummia. Insieme ad alcuni vasi di terra cotta si trovavano ancora parecchi altri oggetti di legno: alcuni rotti, forse calpestati, altri apparentemente intatti, e fra questi qualche statuetta del defunto, alcuni modelli di barca, un bel modello di granaio: oggetti tutti colorati e conservanti una grande freschezza di colore. (...) Solo alcune fotografie - al lampo di magnesio - di questi oggetti, prese sotto la minaccia di un gran lastrone della volta che stava lì lì per cadere, hanno lasciato in noi un ricordo di quella visione, pieno di tanto rammarico. - Soprattutto pregevole la fotografia della copertura di una barca su cui si vedono appesi gli scudi di cinque guerrieri - ricordanti perfettamente gli scudi medievali del contorno eguale, ma dalla decorazione singolarmente variata, atta a rivelare un fine senso estetico e decorativo in quel primitivo artista o semplice artigiano." Marro, Atti per il Progresso delle Scienze 17 (1929).

${ }^{12}$ In the photographic archive of the Italian mission there are indeed several instances of small groups of sequentially numbered plates relative to objects from the same tomb, or showing views of the same excavation area. This could be one of them.

13 "Insieme alla suppellettile fittile e ad una iscrizione, furono solamente salvati la scala accennata, un bel frammento di portatrice di offerte, stuccato e dipinto, e, pregevolissimo, il rivestimento interno dell'ultimo sarcofago, attaccato alla cassa con perni di legno". Marro, Atti per il Progresso delle Scienze 17 (1929).

${ }^{14}$ The number was originally left blank by Schiaparelli.

15 "Modello di imbarcazione: frammenti della tenda sulla tolda con gli scudi di pelli bovine appoggiati."

${ }^{16}$ Jones, Boats, 1995, p. 16.

${ }^{17}$ Jones, Boats, 1995, pp. 30-31. For boat O, see “Travelling Boat Being Rowed” in The Met Collection, https://www.metmuseum.org/art/collection/ search/544214.

${ }^{18}$ Winlock, Models of Daily Life in Ancient Egypt, 1955, pp. 45-57, pls. 39-41.

${ }^{19}$ Reisner, Models of Ships and Boats, 1913 p. II.

${ }^{20}$ Merriman, Egyptian Watercraft Models, 2011.

${ }^{21}$ Glanville and Faulkner, British Museum, II: Wooden Model Boats, 1972, pp. 7-8.

${ }^{22}$ Found in Deir el-Bahari (Temple). Reisner, Models of Ships and Boats, 1913, no. 4910, p. 65.

${ }^{23}$ Cairo Museum, no number: Merriman, Egyptian Watercraft Models, 2011, p. 329; Kamal, ASAE 11 (1911), p. 24.

${ }^{24}$ See the ship model in the database of the Rijksmuseum van Oudheden http://www.rmo.nl/ collectie/zoeken?object=AH+63. Rijksmuseum van Oudheden, Leiden, inv. AH 63; Merriman, Egyptian Watercraft Models, 2011, p. 334.

${ }^{25}$ Metropolitan Museum of Art, New York, 11.150.9; Merriman, Egyptian Watercraft Models, 2011, p. 355; Kamal, ASAE 11 (1911), p. 28.

${ }^{26}$ The tomb is still dated generically to the "First Intermediate Period". Leospo, in Donadoni Roveri et al. (eds.), Gebelein, 1994, pp. 45-54; Moiso, in Museo Egizio, 2015, pp. 63-69.

${ }^{27}$ The monkeys are barely visible in the painting today (only one can be made out), but are mentioned in the journal of the excavator, Virginio Rosa, now in the State Archive in Turin (Italy). Archivio di Stato di Torino, fondo MAE, $2^{\circ}$ vers., m. 5, n. 2, p. 16.

${ }^{28}$ Newberry, Beni Hasan, I, 1893, pls. XIV, XXIX. 
${ }^{29}$ Shaw, Egyptian Warfare and Weapons, 1991, p. 25.

${ }^{30}$ Spalinger, in Moreno Garcia, Ancient Egyptian Administration, 2013, pp. 450-51; Arnold, Metropolitan Museum Journal 26 (1991), pp. 5-48.

${ }^{31}$ As suggested by Tooley, "Middle Kingdom Burial Customs", 1989, p. 62, who suggests that the actual shields found in tombs may have had the same purpose. So did, she argues, the two model battalions found in Mesehti's tomb at Asyut. He was the local governor of Asyut at the end of the Eleventh Dynasty, and his models (CG257-258) constitute the most articulate expression of his will to manifest his power in the afterlife, as well as possibly providing magical protection of the tomb against robbers and enemies.

32 Spalinger, in Moreno Garcia, Ancient Egyptian Administration, 2013, p. 449; Fischer, Kush 9 (1961), pp. 44-80.

${ }^{33}$ Allen, in Manuelian (ed.), Studies in Honor of W.K. Simpson, I, 1996, p. 1.

${ }^{34}$ Since the cabins of model boats always have the same number of shields on either side, this obviously must have been ideally true for painted boats as well.

${ }^{35}$ Merriman, Egyptian Watercraft Models, 2011, p. 100.

${ }^{36}$ Ashmolean Museum of Oxford, E. 2297; Merriman, Egyptian Watercraft Models, 2011, p. 321.

${ }^{37}$ The British Museum Database, BM EA 41574, (http:// www.britishmuseum.org/research/collection_online/ collection_object_details/collection_image_gallery. aspx?assetId $=230872001 \&$ objectId $=163635$ \&partId=1); Merriman, Egyptian Watercraft Models, 2011, p. 333; Glanville and Faulkner, British Museum, II: Wooden Model Boats, 1972, pp. 22-25.

${ }^{38}$ Museum, Art Gallery and Aquarium Bolton (UK), 1920.10.1; Merriman, Egyptian Watercraft Models, 2011, p. 328.

${ }^{39}$ Petrie and Brunton, Sedment, I, 1924, p. 10.

${ }^{40}$ Royal Museum of Scotland, Edinburgh, A.1921.1658; Merriman, Egyptian Watercraft Models, 2011, p. 233.

${ }^{41}$ Victoria Museum for Egyptian Antiquities, University of Uppsala (Sweden), 355; Merriman, Egyptian Watercraft Models, 2011, p. 235.

${ }^{42}$ Oriental Institute Museum, University of Chicago, 11492; Merriman, Egyptian Watercraft Models, 2011, p. 236.

${ }^{43}$ Museum of Fine Arts, Boston, 21.877 (https://www. mfa.org/collections/object/model-of-a-transportboat-with-a-portable-cabin-143887), 21.895 (https://www.mfa.org/collections/object/model-ofa-transport-boat-with-a-portable-cabin-143969), 21.830 (https://www.mfa.org/collections/object/ model-of-a-transport-boat-with-a-portablecabin-143831), 21.489 (https://www.mfa.org/ collections/object/model-of-a-transport-boatwith-portable-cabin-143764); Merriman, Egyptian Watercraft Models, 2011, pp. 297, 302, 310.

${ }^{44}$ Semitic Museum, Harvard University, 1902.16.3; Merriman, Egyptian Watercraft Models, 2011, p. 309.

${ }^{45}$ Cairo JE 34292; Merriman, Egyptian Watercraft Models, 2011, p. 345

${ }^{46}$ Rijskmuseum van Oudheden, Leiden, inv. F 1939/1.2 (http://www.rmo.nl/collectie/ zoeken?object=F+1939\%2f1.2); Merriman, Egyptian
Watercraft Models, 2011, p. 255.

${ }^{47}$ JE 4952, Reisner, Models of Ships and Boats, 1913, pp. 105-06.

${ }^{48}$ Metropolitan Museum of Art, New York, 20.3.6; Merriman, Egyptian Watercraft Models, 2011, p. 254; Winlock, Models of Daily Life, 1955, pl. 51.

${ }^{49}$ Cairo CG 4910; Merriman, Egyptian Watercraft Models, 2011, p. 356.

50 Ägyptologisches Museum, Universität Leipzig, 36 and 38; A. Merriman, Egyptian Watercraft Models, 2011, p. 335.

${ }^{51}$ Cairo JE 45318; A. Merriman, Egyptian Watercraft Models, 2011, p. 377.

${ }^{52}$ Cairo JE 37564a-186; Ashmolean Museum, University of Oxford (UK), E.2301; Merriman, Egyptian Watercraft Models, 2011, pp. 284, 289.

${ }^{53}$ Egyptian Museum JE 37564d.

${ }^{54}$ Rosicrucian Egyptian Museum, San José, California, 1815; British Museum, inv. EA 34273; Merriman, Egyptian Watercraft Models, 2011, pp. 341, 342.

${ }^{55}$ Cairo JE 39127.

${ }^{56}$ Shaw, Egyptian Warfare and Weapons, 1995, p. 34.

${ }^{57}$ Wernick 2016, JSSEA 41 (2014-2015), pp. 50-51.

${ }^{58}$ Spalinger, in Moreno Garcia, Ancient Egyptian Administration, 2013, p. 449; Fischer 1961, Kush 9 (1961), pp. 44-80.

${ }^{59}$ See Table 2 above.

${ }^{60}$ Wernick 2016, JSSEA 41 (2014-2015), p. 55; Osirisnet, https://www.osirisnet.net/popupImage.php?img=/ tombes/nobles/houy40/photo/houy40_cd_ P1210999_01.jpg\&lang=en\&sw=1920\&sh=1080.

${ }^{61}$ Arnold, Metropolitan Museum Journal 26 (1991), p. 25.

${ }^{62}$ Vandier, Manuel d'Archéologie égyptienne, 1978, pl. XXI; Blackman, JEA 6 (3), 1920.

${ }^{63}$ Tooley, “Middle Kingdom Burial Customs”, 1989, pp. 89-92; Tooley, Egyptian Models and Scenes, 1995, pp. 36-40.

${ }^{64}$ Tooley, “Middle Kingdom Burial Customs”, 1989, pp. 89-91, 94.

${ }^{65}$ JE 52085-6; Tooley, “Middle Kingdom Burial Customs”, 1989, p. 94; Fischer, Kush 9 (1961), p. 49.

${ }^{66}$ Kroenke, The Provincial Cemeteries of Naga ed-Deir, 2010, p. 209. p. 369.

${ }^{67}$ S. 10745 , S. 11960 , S. 15802.

${ }^{68}$ Steindorff, Grabfunde des Mittleren Reichs in den königlichen Museen zu Berlin, 1896-1901, pl. IV.

${ }^{69} \mathrm{http}: / /$ meketre.org/repository/theme/1048576; Vandier, Manuel d'archéologie égyptienne, 1978, p. 276.

${ }^{70}$ Osirisnet, https://www.osirisnet.net/tombes/moalla/ ankhtifi/e_ankhtifi_02.htm; Vandier, Moalla, 1950.

${ }^{71}$ Vandier, Moalla, 1950.

${ }^{72}$ Offering formula on her sarcophagus, now in Cairo Museum. Winlock, Excavations at Deir el Bahri: 19111931, 1942.

${ }^{73}$ Vandier, Manuel d'archéologie égyptienne, 1978, p. 231; Naville, Deir el Bahari, I, 1907, pl. XX. Offering formula on her sarcophagus, now in Cairo Museum, JE 47397.

${ }^{74}$ PM, I, p. 437. Vandier, Manuel d'archéologie égyptienne, 1978, p. 230.

75 Davies, The Tomb of Antefoker, 1920.

${ }^{76}$ Newberry, Beni Hasan, I, 1893a, pl. XIII. On the walls of the tomb of Khnumhotep III were some paintings 
of granaries, but without a dome. Pl. XIX.

${ }^{77}$ Vandier, Manuel d'archéologie égyptienne, 1978, p. 238; Rosellini, Monumenti civili, 1832-1844, pl. XXXV.

${ }^{78}$ Newberry, Beni Hasan, II,1893, pl. XVIII.

${ }^{79}$ Blackman, The Rock Tombs of Meir, IV, 1924, pls. XVIII, XXIII.

${ }^{80}$ De Buck labels the spell on the inner coffin as G1T and the one on the side of the outer coffin G2T. The original of G2T has perished (it was likely left inside the tomb, like many other objects), and it is only visible in photographs. PM, V, p. 163; De Buck, G1T and G2T; Carrier, Textes des sarcophages du Moyen Empire Égyptien, I, 2004, pp. 790-805; Wagner, in Bickel et al. (eds.), Studies in Ancient Egyptian Funerary Literature, 2017, pp. 553-97.

${ }^{81}$ Leospo, in Donadoni Roveri et al. (eds.), Gebelein, 1994, pp. 45-54.

82 The coffin of Iqer originally had the inventory number S. 15774 ("Rivestitura interna di sarcofago, con coperchio, coperto di iscrizioni e disegni”), later erroneously changed to S. 15744, a number actually given to another coffin, containing a mummy, in Schiaparelli's handwritten inventory ("cassa con mummia"). However, some publications, such as Donadoni Roveri et al., Il Museo Egizio di Torino, 19932, p. 198, and the more recent Fiore Marochetti, in Wendrich (ed.), UEE, 2013, p. 8 (https://escholarship. org/content/qt2j11p1r7/qt2j11p1r7.pdf), maintain the correct original inventory number (S. 15774).

${ }^{83}$ With the probable addition of 30 jars (S. 15761-72, S. 15780-97), which in Schiaparelli's manuscript inventory are joined to the rest of Iqer's items by a bracket, with their total value of 3000 Italian lire marked next to them. The Italian Egyptologist used this recording system only for burial assemblages, and only occasionally. A study of these jars in the future may help to further narrow down the chronology of this burial.

${ }^{84}$ Roccati, in Willems (ed.), The World of the Coffin Texts, 1996, pp. 109-13; Roccati, Oriens Antiquus 6 (1967), pp. 169-80; Roccati, in Donadoni Roveri (ed.), La vita quotidiana, 1987, p. 35, fig. 27; Curto, in PosenerKriéger (ed.), Mèlanges, I, 1985, p. 173; Donadoni Roveri, in Robins (ed.), Beyond the Pyramids, 1990, p. 27, fig. 3.8.

${ }^{85}$ Willems, Egyptian Funerary Culture, 2014, pp. 195-96; Morenz, Die Zeit der Regionen im Spiegel der GebeleinRegion, 2010, pp. 409-10, 418-20; Willems, The Coffin of Heqata, I, 1996, see the introduction, especially p. 23; Willems, Chests of Life, 1988, p. 247; Neugebauer, Egyptian Astronomical Texts, I, 1960, pp. 12-13.

${ }^{86}$ Roccati, in Willems (ed.), The World of the Coffin Texts, 1996, pp. 109-13; Roccati, Oriens Antiquus 6 (1967), pp. 169-80; Roccati, in Donadoni Roveri (ed.), $L a$ vita quotidiana, 1987-1989, p. 35, fig. 27; Curto, in Posener-Kriéger (ed.), Mélanges, I, 1985, p. 173; Donadoni Roveri, in Robins (ed.), Beyond the Pyramids, 1990, p. 27, fig. 3.8; Leospo, in Donadoni Roveri et al. (eds.), Gebelein, 1994, pp. 45-54.

${ }^{87}$ Steindorff, Grabfunde des Mittleren Reichs, I, 1896 and Steindorff, Grabfunde des Mittleren Reichs, II, 1901, pp. 24-25; PM, V, p. 162.
${ }^{88}$ Tooley, “Middle Kingdom Burial Customs”, 1989, pp. 31, 114.

89 Tooley, in Eyre et al. (eds.), The Unbroken Reed, 1994, pp. 343-53; Brovarski, in Johnson and Wente (eds.), Studies in Honor of George R. Hughes, 1976, pp. 34-36.

${ }^{90}$ Virginio Rosa's journal excavation, Archivio di Stato in Turin, MAE fund, $2^{\circ}$ vers., m. 5, n. 2.

${ }^{91}$ Eschenbrenner-Diemer, in Miniaci et al. (eds.), Company of Images, 2017, pp. 133-91.

${ }^{92}$ Eschenbrenner-Diemer, in Miniaci et al. (eds), Company of Images, 2017, pp. 154-66.

\section{Bibliography}

Allen, James P., "Some Theban Officials of the Early Middle Kingdom”, in: Peter Der Manuelian (ed.), Studies in Honour of W.K. Simpson, I, Boston 1996.

Arnold, Dorothea, "Amenemhat I and the Early Twelfth Dynasty at Thebes”, MMJ 26 (1991), pp. 5-48.

Blackman, Aylward M., "A Painted Pottery Model of a Granary in the Collection of the Late Jeremiah James Colman, Esq., of Carrow House, Norwich", JEA 6/3 (1920), pp. 206-08.

Blackman, Aylward M. and Michael R. Apted, The Rock Tombs of Meir, IV: The Tomb-Chapel of Pepi Onkh the Middle Son of Sebkhotpe and Pekhernefert (ASEg 28), London 1954.

Brovarski, Edward, "Two Monuments of the First Intermediate Period from the Theban Nome" in: Janet H. Johnson and Edward F. Wente (eds.), Studies in Honor of George R. Hughes, Chicago 1976, pp. 31-41.

Carrier, Claude, Textes des Sarcophages du Moyen Empire Égyptien, I, Monaco 2004.

Curto, Silvio, "Gebelein: Prospettive di ricerca”, in: Paule Posener-Kriéger (ed.), Mèlanges Gamal Eddin Mokhtar, I (BiEtud 97/2), Le Caire 1985, pp. 167-75.

Davies, Norman de Garis, The Tomb of Antefoker, Vizier of Sesostris I, and of His Wife, Senet (no. 60) (Theban Tombs Series 2), London 1920.

De Buck, Adriaan, The Egyptian Coffin Texts, Chicago 1935-1961.

Del Vesco, Paolo and Beppe Moiso (eds.), Missione Egitto 1903-1920: L'avventura archeologica M.A.I. raccontata, Modena 2017.

Donadoni Roveri, Anna Maria, “Gebelein”, in: Gay Robins (ed.), Beyond the Pyramids: Egyptian Regional Art from the Museo Egizio, Turin, Atlanta 1990, pp. 23-29.

Donadoni Roveri, Anna Maria, Enrichetta Leospo, Elvira D’Amicone, Alessandro Roccati and Sergio Donadoni, Il Museo Egizio di Torino: Guida alla lettura di una civiltà, Novara 19932 .

Donadoni Roveri, Anna Maria, Elvira D’Amicone and Enrichetta Leospo (eds.), Gebelein: Il villaggio e la necropoli, Torino 1994.

Eschenbrenner-Diemer, Gersande, "From the Workshop to the Grave: The Case of Wooden Funerary Models", in: Gianluca Miniaci, Marilina Betrò and Stephen Quirke, (eds.), Company of Images: Modelling the Imaginary World of Middle Kingdom Egypt (2000-1500 $B C)$. Proceedings of the International Conference of the EPOCHS Project held $18^{\text {th }}-20^{\text {th }}$ September 2014 at UCL, London (OLA 262), Leuven 2017, pp. 133-91.

Farina, Giulio, “Notizie sugli scavi della Missione 
Archeologica Italiana a Gebelein 1930", Aegyptus 10 (1930), pp. 291-94.

Farina, Giulio, “Gli scavi della Missione Egittologica Italiana in Egitto: 1934-1937”, Oriente Moderno 17 (1937), p. 357.

Fiore Marochetti, Elisa, “Gebelein”, in: Willeke Wendrich (ed.), UCLA Encyclopedia of Egyptology, Los Angeles 2013, https://escholarship.org/content/qt2j11p1r7/ qt2j11p1r7.pdf .

Fischer, Henry George, “The Nubian Mercenaries of Gebelein During the First Intermediate Period", Kush 9 (1961), pp. 44-80.

Glanville, Stephen R. K. and Raymond O. Faulkner, Catalogue of Egyptian Antiquities in the British Museum, II: Wooden Model Boats, London 1972.

Jones, Dilwyn, Boats (Egyptian Bookshelf), London 1995. Kamal, Ahmed, "Rapport sur les fouilles exécutées dans la zone comprise entre Déîrout, au nord, et Déîr-elGanadlah, au sud", ASAE 11 (1911), pp. 3-39.

Kroenke, Karin R., The Provincial Cemeteries of Naga edDeir: A Comprehensive Study of Tomb Models Dating from the Late Old Kingdom to the Late Middle Kingdom, Barkeley 2010.

Leospo, Enrichetta, "La necropoli dalla fine dell'Antico Regno al Medio Regno”, in: Anna Maria Donadoni Roveri, Elvira D’Amicone and Enrichetta Leospo (eds.), Gebelein: Il villaggio e la necropoli, Torino 1994, pp. 41-59.

Marro, Giovanni, “L'esplorazione della necropoli di Gebelên (dai lavori della Missione Archeologica Italiana in Egitto)", in: Atti della Società Italiana per il Progresso delle Scienze 17 (1929), Torino 15-22 settembre 1928, pp. 592-636.

Merriman, Ann, Egyptian Watercraft Models from the Predynastic to Third Intermediate Period (BAR-IS 2263), Oxford 2011.

Morenz, Ludwig, Die Zeit der Regionen im Spiegel der Gebelein-Region, Leiden 2010.

Moiso, Beppe, Ernesto Schiaparelli e la tomba di Kha, Torino 2008.

Moiso, Beppe, "La tomba di Iti e Neferu”, in: Museo Egizio, Modena 2015, pp. 63-69.

Moiso, Beppe, La storia del Museo Egizio, Modena, 2016.

Naville, Édouard, The XI ${ }^{\text {th }}$ Dynasty at Deir el-Bahari, I (EEF 28), London 1907.

Neugebauer, Otto and Richard A. Parker, Egyptian Astronomical Texts, I: The Early Decans (BEStud 3), Providence (RI) 1960.

Newberry, Percy, Beni Hasan, London 1893.

Petrie, W.M. Flinders and Guy Brunton, Sedment, I (BSAE 34), London 1924.

$P M, \mathrm{I}=$ Porter, Bertha and Rosalind L.B. Moss, Topographical Bibliography of Ancient Egyptian Hieroglyphic Texts, Reliefs, and Paintings, I. The Theban Necropolis, Oxford 1960.

$P M, \mathrm{~V}=$ Porter, Bertha and Rosalind L.B. Moss, Topographical Bibliography of Ancient Egyptian Hieroglyphic Texts, Reliefs, and Paintings, V. Upper Egypt: Sites, Oxford 1968.

Reisner, George A., Models of Ships and Boats, nos. 47984976 and 5034-5200 (CGC 68), Cairo 1913.

Roccati, Alessandro, "Sulla tradizione dei 'sarcofagi”,
OrAnt 6 (1967), pp. 169-80.

Roccati, Alessandro, “Arte e tecnica della scrittura”, in: Anna Maria Donadoni Roveri (ed.), La civiltà degli Egizi : La vita quotidiana, Torino 1987, pp. 20-45.

Roccati, Alessandro, "A Ghost Tomb and a Torn Papyrus with Coffin Texts in Turin”, in: Harco Willems (ed.), The World of the Coffin Texts: Proceedings of the Symposium Held on the Occasion of the 100 th Birthday of Adriaan De Buck, Leiden, December 17-19, 1992, Leiden 1996, pp. 109-13.

Rosellini, Ippolito, I monumenti dell'Egitto e della Nubia disegnati dalla spedizione scientifico-letteraria toscana in Egitto, distribuiti in ordine di materie interpretati ed illustrati dal dottore Ippolito Rosellini, Pisa 1832-1844.

Schiaparelli, Ernesto, "La missione italiana a Ghebelein", ASAE 21 (1921), pp. 126-28.

Schiaparelli, Ernesto, Relazione sui lavori della Missione Archeologica Italiana in Egitto (anni 1903-1920), I : Esplorazione della "Valle delle Regine" nella necropoli di Tebe, Torino 1924.

Schiaparelli, Ernesto, Relazione sui lavori della Missione Archeologica Italiana in Egitto (anni 1903-1920), II: La tomba intatta dell'architetto "Cha" nella necropoli di Tebe, Torino 1927.

Seidlmayer, Stephan, “The First Intermediate Period (c. 2160-2055 BC)”, in: Ian Shaw (ed.), The Oxford History of Ancient Egypt, Oxford 2000, pp. 118-47.

Shaw, Ian, Egyptian Warfare and Weapons (ShirEgypt16), Princes Risborough 1991.

Spalinger, Anthony, "The Organization of the Pharaonic Army (Old to New Kingdom)", in: Juan Carlos Moreno Garcia, Ancient Egyptian Administration (Handbook of Oriental Studies. Section 1. The Near and Middle East 104), Leiden 2013, pp. 450-51.

Steindorff, Georg, Grabfunde des Mittleren Reichs in den königlichen Museen zu Berlin, I: Das Grab des Mentuhotep (Mittheilungen aus den orientalischen Sammlungen 8), Berlin 1896.

Steindorff, Georg, Grabfunde des Mittleren Reichs in den königlichen Museen zu Berlin, II: Der Sarg des Sebko.-Ein grabfund aus Gebelên (Mittheilungen aus den orientalischen Sammlungen 9), Berlin 1901.

Tooley, Angela M.J., "Middle Kingdom Burial Customs: A Study of Wooden Models and Related Materials" (doctoral dissertation, University of Liverpool), Liverpool 1989.

Tooley, Angela M.J., "Notes on Wooden Models and the Gebelein Style”, in Christopher Eyre, Anthony Leahy and Lisa Montagno Leahy (eds.), The Unbroken Reed: Studies in the Culture and Heritage of Ancient Egypt in Honour of A. F. Shore (EES, Occasional Publications 11), London 1994, pp. 343-53.

Tooley, Angela M.J., Egyptian Models and Scenes (ShirEgypt 22), Princes Risborough 1995.

Vandier, Jacques, Moalla: la tombe d'Ankhtifi et la tombe de Sébekhotep, (BdE 18), Le Caire 1950.

Vandier, Jacques, Manuel d'Archéologie ègyptienne, VI : basreliefs et peintures, scènes de la vie agricole à l'Ancien et au Moyen Empire, Paris 1978.

Wagner, Mareike, "Die Sprüche 648 bis 654 der altägyptischen Sargtexte” in Susanne Bickel and Lucía Díaz-Iglesias (eds.), Studies in Ancient Egyptian 
Funerary Literature (OLA 257), Leuven 2017, pp. 553-97.

Wernick, Nicholas, “Ancient Egyptian Shields and Their Handles: A Functional Explanation of New Kingdom Developments", JSSEA 41 (2014-2015), pp. 47-83.

Willems, Harco, Chests of Life: A Study of the Typology and Conceptual Development of Middle Kingdom Standard Class Coffins (MVEOL 25), Leiden 1988.

Willems, Harco, The Coffin of Heqata (Cairo JdE 36418): A Case Study of Egyptian Funerary Culture (OLA 70), Leuven 1996.

Willems, Harco, Historical and Archaeological Aspects of Egyptian Funerary Culture: Religious Ideas and Ritual Practice in Middle Kingdom Elite Cemeteries (Culture and History of the Ancient Near East 73), LeidenBoston 2014.

Winlock, Herbert E., Excavations at Deir el Bahri: 19111931, New York 1942.
Winlock, Herbert E., Models of Daily Life in Ancient Egypt: From the Tomb of Meket-Re' 'at Thebes (PMMA 18), Cambridge (MA) 1955.

\section{Online sources}

Meketre Scene Repository, http://meketre.org/

Museum of Fine Arts, Boston, Collections Search, https:// collections.mfa.org/collections

Osirisnet. Tombs of Ancient Egypt, by Thierry Benderitter, https://www.osirisnet.net/e_centrale.htm

Rijksmuseum van Oudheden, Collectie, https://www.rmo. $\mathrm{nl} /$ collectie/

The British Museum collection database $=$ British Museum, Collection Online, https://www. britishmuseum.org/collection

The Met Collection, https://www.metmuseum.org/art/ collection 